\title{
The Emerging Factors Affecting China's Outward Foreign Direct Investments
}

\author{
${\text { Caiazza Rosa }{ }^{1, *} \& \text { Volpe Tiziana }}^{2}$ \\ ${ }^{1}$ Professor of Management at Parthenope University of Naples, Italy \\ ${ }^{2}$ Researcher at the National Research Council (CNR), Italy \\ *Corresponding author: Professor of Management at Parthenope University of Naples, Italy, Via Generale Parisi 13, \\ 80132, Napoli, Italy. E-mail: rosa.caiazza@uniparthenope.it
}

Received: December 13, 2013 Accepted: January 14, $2014 \quad$ Online Published: March 24, 2014

doi:10.5430/mos.v1n2p18 URL: http://dx.doi.org/10.5430/mos.v1n2p18

\begin{abstract}
The paper aims to evidence causes and effects of China's outward foreign direct investment. The article evidences how firms have to become able to turn risks of crisis in opportunities to become global players. It also provides new perspectives on internationalization strategies of Chinese companies.
\end{abstract}

Keywords: cross-border M\&A; emerging economies; developed countries

\section{Theoretical Background}

Merging with or acquiring a foreign company could be the cheapest and fastest way to acquire strategic assets such as know-how, brand names, local permits and licenses (Anand \& Delios, 2002), to exploit complementarities among firms’ capabilities (Barkema \& Vermeulen, 1998; Madhok, 1997), to reinforce networks, to expand production and markets internationally, to gain efficiency through synergies and size (Vasconcellos \& Kish, 1998), to tap new markets, new customers and new distribution channels, to obtain new technology and brands, to access experienced management, to increase overall scale and to remove a competitor or potential competitor (Caiazza, 2012).

Cross-border M\&A are also realized to use existing resources for achieving a competitive advantage in the destination market, to obtain new resources imperfectly mobile across countries or to reinforce firm competitiveness in the home country (Caiazza et al., 2013). Moreover, firms based in emerging economies acquire firms based in developed economies to achieve new resources and capabilities and to operte in new competitive market in which existing firms are not jet able to operate (Hoskisson et al., 2004; Cohen \& Leventhal, 1990, Cantwell, 1992; Frost et al., 2002). Firms with strong networks and well developed social capital may facilitate cooperation in developing knowledge and transferring it to businesses in the home country (Wright et al., 2005; Andersen, 1997). Thus, business groups with strong social capital coming from emerging economies are likely to find their operations impeded when positioning themselves in developed economies compared to other emerging economies (Wright et al., 2005). These firms develop network capabilities to overcome their lack of market institutions in emerging economies (Carbonara \& Caiazza, 2010; Lant et al., 1992; Caiazza, 2013; Carbonara \& Caiazza 2008a, 2008b, 2008c; Wright et al., 2005).

Although the growth of new economies have not changed the rationale that underpins cross-border M\&A, the global flow of foreign direct investment realized through cross-border M\&A has changed (Shimizu et al., 2004; WIR, 2008, 2013). The new global scenario has opened up a window of opportunity for Chinese firms leading them to chose ctross-border M\&A as way to compete globally (Hitt et al., 1998a, 1998b). In this scenario, Chinese national champions are going abroad acquiring firms alla aroud the world (Kogut \& Singh, 1988). Their decisions are aimed to acquire raw materials, technical know-how and strategic assets to reinforce the value chain, gain access to foreign markets, sell their goods and also bypass any protectionist measures (Carbonara \& Caiazza 2009a, 2009b, 2009c). To succeed abroad, Chinese companies have to adapt themselves to local market. That means hiring local managers, investing in local research and placating local concerns for example by listing subsidiaries locally (Brouthers \& Brouthers, 2000; Hitt, 2000; Zaheer, 1995). As it invests in the global economy, so its interests will become 
increasingly aligned with the rest of the world's and as that happens its enthusiasm for international co-operation may grow.

With all the experiences and lessons learned from firms operating on its home, China is becoming stronger and growing its own global companies, relying on its leading economy and the world's largest foreign exchange reserves. Europe is becoming a natural destination for Chinese firms' direct investment, given its huge market, leading-edge technologies, and easy access to the world financial market. Typically, these investments are not done through a well coordinated plan of the Chinese government, but through fragmented deals by individual companies, some state-controlled and some privately owned. Nonetheless, Chinese government leadership is interested in establishing some globally competitive firms acquiring some champions of European Union. At the aim to evidence causes and effects of China's outward foreign direct investment in Europe we present and discuss some case studies.

\section{Methodology}

This research is based on some case study able to evidence causes and effects of China's outward foreign direct investment in Europe. We chose case studies because the object under study is difficult to quantify in a different way. Some interviews were held with managers, advisors and scholars to collect information and data on our cases. The empirical findings of the case studies refine the theretical framework presented in the previous section.

\section{Case Study}

Chinese corporates have proven to be the savior of a number of European corporates. Now, however, they are also coming to the rescue of destitute European governments. A Beijing-based electric power transmission and distribution giant (Company A) acquired 25\% stake in Portuguese national power and gas grid operator (Company B). Under pressure of the global financial crisis, the Portuguese government agreed to reduce its deficit and approved a decree authorizing the sale of a 51\% stake in the Portuguese national power and gas grid operator (Company B). This move quickly led to informal expressions of interest of corporation from China, Oman and Spain, Canada and UK. For Spain, Canada and UK the end of the road came when the Portuguese government announced that only $40 \%$ of the planned $51 \%$ divestiture would take place in the first round of privatization and that bidders had to buy a stake of between $5 \%$ to $25 \%$ of the Company B. In the end, Portuguese corporation's existing shareholders approved of the $25 \%$ stake sale to China's Company A.

Investors were also heartened by the fact that as part of the deal, Chinese firm didn't only create a smart grid production plant in Portugal, it also allowed Portuguese corporation to participate in renewable energy ventures in China. Wider financial markets also approved of the news, with Portuguese corporation's share price rising 8.5\% over the one month after the acquisition from Company A compared to its share price one day prior to the deal announced. Company A acquisition was just part of an overall $40 \%$ stake sale of Company B that was acquired for the remaing part from Oman Company C. As portuguese corporation's principle partner Chinese Company A appointed its own senior management in the board of portuguese corporation and provideed direction for the development of the company's new strategic vision.

Chinese firm A acted as strategic partner of Portuguese firm B leading it to realize some operations abroad. A joint venture was realized as a means for the two firms to enter into the Angolan and Mozambican markets. Later, Chinese and Portuguese corporation began negotiations with the Mozambiquan government on the acquisition of a minority stake in the country's hydroelectric providers. The successful completion of the deal enabled Portuguese corporation to be involved in a project for an electricity transmission system between the southern areas of the country and neighboring nations.

The acquisition also opened the way for the Portuguese partnership to develop energy facilities in Angola, Mozambique and Brazil. Thus, Company A went in Brazil and provided technical advice to portuguese Company B with the express intention of identifying three transmission grid projects for joint investment. Indeed, according to the General Manager of Chinese Company A, portuguese corporation's excellent electric power and gas network and its significant influence in Portugal, Africa and South America was the most likely the primary reason why Chinese firm was interested in portuguese corporation in the first place.

At the same time, another Chinese-based Company D was engineering the largest-ever M\&A transaction of a Polish target. The transaction involved the acquisition of the civilian arm of the Polish steel mill and manufacturer (Company E), by a global Chinese construction manufacturer based in Liuzhou (Company D) from the Polish 
Government. The deal announcement came after a memorandum of cooperation, followed by a preliminary agreement announcement. In fact, the deal agreement represented the culmination of over one year of deal intense negotiations. The acquisition allowed the Chinese Company $\mathrm{D}$ to obtain core technologies that helped it advance some of its product designs and supplement its already-large and diverse product range. The deal also enabled the Company D to establish a manufacturing and logistical footprint in Europe.

The Polish Company E was part of the fabric of life in the district of Poland and was the lifeblood of the community. Given this history, perhaps it was all the more surprising that this deal involving a foreign buyer was ultimately consummated. This was especially true in light of the number of obstacles that had the potential to derail the transaction along the way. The first of these obstacles was polish firm's history and its close, long-running association with the Polish armed forces. That the transaction managed to avoid any problematic national security issues was a tribute to the diplomatically-minded deal makers, as was the solution to the second obstacle to be encountered - the agreement with polish firm's labor unions that was struck following long-running negotiations. It was not the first time that a Chinese firm run into national security issues when transacting abroad.

The polish Company E is currently the largest Polish manufacturer of artillery weapons and has been manufacturing a large number of military vehicles, including tanks and armored vehicles. As a result, there was obvious potential for significant concerns stemming from the Polish government. In the case of the polish/chinese firm tie-up, it is therefore to the credit of both the Chinese and Polish parties that they managed to structure the transaction in such a way that national security concerns didn't throw a spanner in the works. Polish firm's production of military equipment remains in the hands of the Polish government with only the civilian arm having been divested. This separation of operations enabled the deal to move forward without too much nationalistic flag-waving that could have potentially put a halt on proceedings. It is perhaps unsurprising that the deal was held up by the protracted nature of negotiations regarding wages and job security between polish firm and the polish workers union following the initiation of the deal. Negotiations began right after the announcement of Chinese firm's intent to acquire polish firm and continued throughout the summer and autumn. Finally, following much wrangling, an agreement was reached demonstrating that as with everything, compromise is key.

\section{Conclusion and Discussion}

In this article, we analyzed international strategies of Chinese firms to compete in new global scenario. Chinese companies have been prolific in venturing outside their domestic markets to strike deals, demonstrating that they are well-managed, efficient and globally competitive and their actions challenge some assumptions, concepts, and findings commonly accepted. The factors driving this new trend and the optimal mode of internationalization for Chinese firms can be learned from firms of different emerging economy countries. Moreover contemporary developments may lead researchers to revisit the existing theory surrounding cross border M\&A. Chinese acquisition of a potuguese firm' case highlights chinese corporates' increasing propensity to look overseas to high growth markets in order to expand their operations as well as their desire to obtain these assets via acquisitions of legacy holding firms back in Europe, which add a veneer of familiarity to the deal. Chinese firm's tie-up with Portuguese corporation is undoubtedly built around accessing new growth markets, not only from a macroeconomic perspective, but also from a market development viewpoint. Yet the benefits from the deal don't only extend one way. For their part, Portuguese corporation get a cash-rich partner willing to bankroll their expansion overseas, while the Portuguese Government gets itself out of a potentially embarrassing situation. Concerning the second discussed case, it is interesting to note that Chinese acquisition in Poland arose while much of beleaguered Europe was looking to China to provide them with a fiscal escape route. The Polish government actually managed to secure significant investment where many of their wider EU counterparts could not. It seems as though if Europe wants China to help bail them out of their debt crisis they will need to stump up more than just bonds and offer attractive, real assets for Chinese investors.

\section{References}

Anand, J., \& Delios, A. (2002). Absolute and Relative Resources as Determinants of International Acquisitions. Strategic Management Journal, 23(2), 119-134. http://dx.doi.org/10.1002/smj.215

Andersen, O. (1997). Internationalization and Market Entry Mode: a Review of Theories and Conceptual Framework. Management International Review, 37(2), 27-42.

Barkema, H.G., \& Vermeulen, F. (1998). International expansion through start-up or acquisition: a learning 
perspective. Academy of Management Journal, 41(1), 7-26. http://dx.doi.org/10.2307/256894

Brouthers, K.D., \& Brouthers, L.E. (2000). Acquisition or greenfield start-up? Institutional, cultural and transaction $\begin{array}{lllll}\text { cost influences. } & \text { Strategic }\end{array}$ http://dx.doi.org/10.1002/(SICI)1097-0266(200001)21:1<89::AID-SMJ85>3.0.CO;2-8

Caiazza R. (2012). Internationalization in Egypt: Risks and opportunities. China-USA Business Review, 11(9), 767-773.

Caiazza R. (2013). Identifying international market opportunities: The case of Italian companies in Egypt. Benchmarking: An International Journal, 21(4), 396-418.

Caiazza R., Hsieh W., Tiwari M., \& Topf D. (2013). M\&A between giants: The fastest way to dominate the world economy. Foresight, 15(2), 228-239. http://dx.doi.org/10.1108/fs-01-2012-0003

Cantwell, J. (1992). The theory of technological competence and its application to international production. In McFeteridge, D. (Ed.), Foreign Investment, Technology and Economic Growth. Calgary: University of Calgary Press.

Carbonara G., \& Caiazza R. (2008a). Unicredit bank CEO’s dilemma agenda: Grow internationally preserving a strong cultural identity. The Business Review Cambridge, 11(1), 201-206.

Carbonara G., \& Caiazza R. (2008b). Cross-border M\&As: New challenges for Italian banks. The Business Review Cambridge, 11(2), 275-281.

Carbonara G., \& Caiazza R. (2008c). From knowledge to dynamic capabilities: Double learning process in unordinary events. The Business Review Cambridge, 11(2), 247-251.

Carbonara G., \& Caiazza R. (2009a). Factors affecting M\&A success: A starting point for the topic renaissance. The Journal of American Academy of Business Cambridge, 15(1), 92-98.

Carbonara G., \& Caiazza R. (2009b). Mergers and acquisitions: Causes and effects. The Journal of American Academy of Business, Cambridge, 14(2), 188-194.

Carbonara G., \& Caiazza R. (2009c). Are disciplined acquisitions able to create exceptional financial performance? The Business Review Cambridge, 14(1), 258-265.

Carbonara G., \& Caiazza R. (2010). How to turn crisis into opportunity: Perception and reaction to high level of uncertainty in banking industry. Foresight, 12(4), 37-46. http://dx.doi.org/10.1108/14636681011062988

Cohen, W., \& Levinthal, D. (1990). Absorptive capacity: a new perspective on learning and innovation. Administrative Science Quarterly, 35, 128-52. http://dx.doi.org/10.2307/2393553

Frost, T. S., Birkinshaw, J., \& Ensign, P. (2002). Centers of excellence in multinational corporations. Strategic Management Journal, 23, 997-1018. http://dx.doi.org/10.1002/smj.273

Hitt, M.A. (2000). The new frontier: transformation of management for the new millennium. Organizational Dynamics, 28, 6-17. http://dx.doi.org/10.1016/S0090-2616(00)88446-6

Hitt, M.A., Harrison, J.S., Ireland, R.D., \& Best, A. (1998a). Attributes of successful and unsuccessful acquisitions of U.S. firms. British Journal of Management, 9, 91-114. http://dx.doi.org/10.1111/1467-8551.00077

Hitt, M.A., Keats, B.W., \& DeMarie, S.M. (1998b). Navigating in the new competitive landscape: building strategic flexibility and competitive advantage in the 21st century. Academy of Management Executive, 12(4), $22-42$.

Hoskisson, R. E., Kim, H., White, R. E., \& Tihanyi, L. (2004). A framework for understanding international diversification by business groups from emerging economies. In Hitt, M. A. and Cheng, J. L. C. (Eds), Theories of the Multinational Enterprise: Diversity, Complexity, and Relevance. Advances in International Management. Vol. 16. Oxford: Elsevier/JAI Press. http://dx.doi.org/10.1016/S0747-7929(04)16008-3

Kogut, B., \& Singh, H. (1988). The effect of national culture on the choice of entry mode. Journal of International Business Studies, 19, 411-432. http://dx.doi.org/10.1057/palgrave.jibs.8490394

Lant, T. K., Milliken, F. J., \& Batra, B. (1992). The role of managerial learning and interpretation in strategic persistence and reorientation: an empirical exploration. Strategic Management Journal, 13, 585-608. http://dx.doi.org/10.1002/smj.4250130803

Madhok, A. (1997). Cost, value and foreign market entry mode: the transaction and the firm. Strategic Management Journal, 18, 39-61. http://dx.doi.org/10.1002/(SICI)1097-0266(199701)18:1<39::AID-SMJ841>3.0.CO;2-J 
Shimizu K., Hitt M.A., Vaidyanath D., \& Pisano V. (2004). Theoretical foundations of cross-border mergers and acquisitions: A review of current research and recommendations for the future. Journal of International Management, 10, 307-353. http://dx.doi.org/10.1016/j.intman.2004.05.005

Vasconcellos, G. M., \& Kish R.J. (1998). Cross-border Mergers and Acquisitions: the European-US Experience. Journal of Multinational Financial Management, 4 831-450. http://dx.doi.org/10.1016/S1042-444X(98)00041-3

WIR (2008) World Investment Report, UNCTAD - United Nations Publication, New York and Geneva.

WIR (2013) World Investment Report, UNCTAD- United Nations Publication, New York and Geneva.

Wright M, Filatotchev I, Hoskisson RE, W., \& Peng MW. (2005). Strategy Research in Emerging Economies: Challenging the Conventional Wisdom. Journal of Management Studies, 42(1), 1-33. http://dx.doi.org/10.1111/j.1467-6486.2005.00487.x

Zaheer, S. (1995). Overcoming the liability of foreignness. Academy of Management Journal, 38, 341-363. http://dx.doi.org/10.2307/256683 